\title{
Diversity and abundance of ants (Hymenoptera: Formicidae) in Phu Luong, Thai Nguyen province, Vietnam
}

\author{
Sụ đa dạng và độ phong phú của các loài kiến (Hymenoptera: Formicidae) ỏ \\ Phú Luoong, tỉnh Thái Nguyên, Việt Nam \\ Research article
}

Nguyen Dai Dac*, Nguyen Lien Thi Phuong

Institute of Ecology and Biological Resources, Vietnam Academy of Science and Technology, 18 Hoang Quoc Viet str., Nghia Do, Cau Giay, Hanoi, Vietnam

\begin{abstract}
Three different habitats: secondary forest, acacia plantation, and mixed forests on limestone, were chosen to determine and compare the ant species diversity in these habitats. A total of 24 identified species and 11 morphology species belonging to 20 genera in seven subfamilies were collected using pitfall traps from June 2014 to May 2015. The Shannon-Wiener's species diversity index indicated that the diversity was the highest in the acacia plantation (2.08), followed by the secondary forest (1.99) and lowest in the mixed forests on limestone (1.83). There are three dominant species in the habitat (I), Pheidole noda, Odontomachus cf. monticola, and Odontoponera denticulate; four dominant species in the habitat (II), Odontoponera denticulata, Carebara diversa, Technomyrmex brunneus and Anoplolepis gracilipes; and only one dominant species in the habitat (III), Anoplolepis gracilipes. The species similarity (S) relatively low may be because of the difference vegetation and condition in the three habitats.
\end{abstract}

Đa dạng loài kiến trong ba môi truờng sống khác nhau: rùng rậm thuoờng xanh nhiệt đới, rù̀ng keo và rùng hồn giao trên núi đá vôi, được nghiên cứu để xác định và so sánh sư đa dạng các loài kiến trong nhũng môi trường sống. Phương pháp nghiên cứu: sủ dụng bẫy hố tù tháng 6 năm 2014 đến tháng 5 năm 2015. Đã ghi nhận được 35 loài, thuộc 20 giống, 7 phân họ. Chỉ số đa dạng loài Shannon-Wiener cho thấy rù̀ng keo có chỉ số đa dạng cao nhất $(2,08)$, tiếp theo là rùng rậm thuờng xanh nhiệt đới $(1,99)$ và cuối cùng là rùng hỗn giao trên núi đá vôi $(1,83)$. Có 3 loài uu thế ở sinh cảnh (I) là Pheidole noda, Odontomachus cf. monticola và Odontoponera denticulata, bốn loài uu thế ở sinh cảnh (II) là Carebara diversa, Technomyrmex brunneus, Odontoponera denticulate và Anoplolepis gracilipes. OỎ sinh cảnh (III) chỉ có duy nhất một loài chiếm uu thế là loài Anoplolepis gracilipes. Chi số tuoong đồng (S) tuoong đối thấp có thể là do sụ khác nhau ở các thảm thực vật và điè̀u kiện sống trong ba sinh cảnh.

Keywords: Formicidae, species diversity, pitfall traps, habitats, Vietnam

\section{Introduction}

Ants (Hymenoptera: Formicidae) are the most dominant insect group on earth, both ecologically and numerically and ants are estimated to represent $10 \%$ to $15 \%$ of the entire animal biomass in many terrestrial ecosystems (Beattie and Hughes 2002). The impact of ants on the terrestrial environment is correspondingly great. They engage in a variety of ecological roles such as: competitors, predators, prey, scavengers, mutualists, gardeners, and soil engineers. Ant is one of the important components of the ecosystem.
They participate in the cyclical process of nature such as nitrogen cycle, carbon cycle, contributing to reducing climate change. Thus, ants can be used as bio-indicators to assess forest quality and environmental controls. Moreover, ants have been used as biological agents of insect pests in agriculture in many countries such as Malaysia (Khoo and Chung, 1989), Thailand (Kritsaneeapiboon and Saiboon, 2000), and Vietnam (Nguyen Thi Thu Cuc, 2005). In addition, environmental changes have an impact on macroarthropod abundance (Pearson and Derr, 1986; Adis and Latif, 1996). Many ant species are highly sensitive to the 
micro climate fluctuations and to habitat structure, and thus respond strongly to environmental change (Anderson, 1990; Alonso, 2000). The research objective is to compare the species diversity of ants at different habitats.

\section{Methodology}

The study sites were located within the Phu Luong district, Thai Nguyen province in north-eastern Vietnam. Three habitats were selected to set up pitfall traps: (I) secondary forest, (II) acacia plantation, (III) mixed forests on limestone. The ants were sampled in four seasons, from June 2014 to May 2015.

Sampling method: Ants were primary collected by pitfall traps, which are made from plastic cups (diameter of $10 \mathrm{~cm}$, height of $13 \mathrm{~cm}$ ), each cup containing $10 \mathrm{~mL}$ alcohol with $4 \%$ formaldehyde. The cup was set on the ground so that its rim was flush with the ground surface. A total of 15 traps were set at each habitat. Ant specimens were collected after 10 days since the trap was set with study liquid (alcohol and formaldehyle), then the trap was left empty 10 days, filled with study liquid again and left for another 10 days to the next collected time. Ant specimens were identified using the identification guides of Bolton (1994), Eguchi et al. (2011, 2014). In addition, Dr. Yamane from Kagoshima University and Dr. Eguchi from Tokyo Metropolitan University also helped to identify ant specimens.

The Shannon-Wiener's diversity index ( $\left.H^{\prime}\right)$ (Krebs, 1999) and Bray-Curtis similarity (S) were used in this study, with formulae as below:

$$
H^{\prime}=\sum_{i=1}^{s}(p i)(\ln p i)
$$

Where, $\mathrm{H}^{\prime}=$ Species diversity index

$\mathrm{s}=$ Number of species

$\mathrm{pi}=$ Proportion of the total sample belonging to $\mathrm{i}$ th species

$$
\mathrm{S}=100\left(1-\frac{\sum_{i}|y i j-y i k|}{\sum_{i} y i j+\sum_{i} y i k}\right)
$$

Where, $\mathrm{S}=$ Bray-Curtis similarity

$\mathrm{y}=$ Number of specimen

$\mathrm{j}, \mathrm{k}=$ habiatas $\mathrm{j}$ and $\mathrm{k}$

$\mathrm{i}=$ species $\mathrm{i}$

$\mathrm{k}$.

$y i j, y i k=$ Number specimen at habitat $j$ and habitat
The evenness index (J') (Krebs, 1999) was calculated to determine the equal abundance of ants in each study site, its formula as follows:

$$
\mathrm{J}^{\prime}=\frac{H^{\prime}}{H^{\prime} M A X}
$$

Where, $\mathrm{H}^{\prime}=$ Observed index of species diversity H'MAX = Maximum possible index of diversity

The software used in this study is Primer 6.

\section{Results and discussion}

A total of 35 ant species in 20 genera distributed among seven subfamilies were collected from three different habitats using pitfall trap (Table 1). Seven species were added to the list publish by Nguyen 82015): Monomorium destructor (Jerdon), Pheidole laevicolor Eguchi, Pristomyrmex punctatus (Smith), Pachycondyla nigrita (Mayr), Nylanderia sp1 of LD, Crematogaster sp3 of LD, and Tetraponera $\mathrm{sp} 5$ of LD. With the comparative ant communities between the three habitats, the highest number of species was recorded in the habitat (II), followed by the habitat (I), and the lowest in the habitat (III). Twenty-eight species of ants in 20 genera and seven subfamilies were found in the habitat (II), follow by 22 species in 15 general and five subfamilies in habitat (I), and there are only 13 species in 10 genera and five subfamily were found in habitats (III). Eight species, Aenictus binghamii Forel, Technomyrmex brunneus Forel, Anoplolepis gracilipes (F. Smith), Carebara diversa (Jerdon), Crematogaster sp2 of LD, Leptogenys peugueti (Andre), Odontoponera denticulata F. smith, Pachycondyla rufipes (Jerdon), were found in all three habitats. Ten species, Gnamptogenys bicolor (Emery), Polyrhachis proxima Roger, Polyrhachis sp2 of LD, Crematogaster sp3 of LD, Monomorium destructor (Jerdon), Pheidole laevicolor Eguchi, Pristomyrmex punctatus (Smith), Anochetus cf. qraeffei Mayr, Tetraponera attenuata (F. Smith), Tetraponerasp5 of LD, were found only in the habitat (II). Two species Aenictus paradentatus Jaitrong \& Yamane and Leptogenys kitteli (Mayr) were found only in the habitat (I). And two species Camponotus sp.3 of LD and Pachycondyla nigrita (Mayr) were found only in the habitat (III). At the genus level of all sites, Pachycondyla has the highest number of species, with 5

\begin{tabular}{|c|c|c|c|c|}
\hline \multirow[t]{2}{*}{ No } & \multirow{2}{*}{ Composition } & \multicolumn{3}{|c|}{ Number of individuals in each habitat } \\
\hline & & (I) & (II) & (III) \\
\hline & Subfamily Dorylinae & & & \\
\hline 1 & Aenictus binghamii Forel & 12 & 2 & 27 \\
\hline 2 & Aenictus paradentatus Jaitrong \& Yamane & 5 & & \\
\hline & Subfamily Dolichoderinae & & & \\
\hline 3 & Dolichoderus thoracicus F. Smith & 3 & 7 & \\
\hline 4 & Dolichoderus sp1 of LD & 1 & & \\
\hline 5 & Technomyrmex brunneus Forel & 37 & 244 & 8 \\
\hline & Subfamily Ectatomminae & & & \\
\hline 6 & Gnamptogenys bicolor (Emery) & & 1 & \\
\hline
\end{tabular}
species.

Table 1. Species composition and their individuals at three habitats in Phu Luong, Thai Nguyen 


\begin{tabular}{|c|c|c|c|c|}
\hline \multirow[t]{2}{*}{ No } & \multirow[t]{2}{*}{ Composition } & \multicolumn{3}{|c|}{ Number of individuals in each habitat } \\
\hline & & (I) & (II) & (III) \\
\hline 8 & Camponotus sp1 of LD & & 35 & 22 \\
\hline 9 & Camponotus sp2 of LD & 1 & & 2 \\
\hline 10 & Camponotus sp3 of LD & & & 2 \\
\hline 11 & Nylanderia sp1 of LD & 1 & 30 & \\
\hline 12 & Polyrhachis proxima Roger & & 1 & \\
\hline \multirow[t]{2}{*}{13} & Polyrhachis sp2 of LD & & 3 & \\
\hline & Subfamily Myrmicinae & & & \\
\hline 14 & Carebara diversa (Jerdon) & 63 & 561 & 84 \\
\hline 15 & Crematogaster sp2 of LD & 2 & 44 & 5 \\
\hline 16 & Crematogaster sp3 of $\mathrm{LD}$ & & 7 & \\
\hline 17 & Monomorium destructor (Jerdon) & & 1 & \\
\hline 18 & Pheidole laevicolor Eguchi & & 3 & \\
\hline 19 & Pheidole noda Smith & 113 & 8 & \\
\hline 20 & Pheidole plainfrons Santschi & 4 & 6 & \\
\hline 21 & Pheidole yeensis Forel & 1 & 20 & \\
\hline \multirow[t]{2}{*}{22} & Pristomyrmex punctatus (Smith) & & 41 & \\
\hline & Subfamily Ponerinae & & & \\
\hline 23 & Anochetus cf. qraeffei Mayr & & 8 & \\
\hline 24 & Diacamma sp1 of LD & 13 & 2 & \\
\hline 25 & Leptogenys kitteli (Mayr) & 5 & & \\
\hline 26 & Leptogenys peugueti (Andre) & 10 & 9 & 36 \\
\hline 27 & Odontomachus cf. monticola Emery & 160 & 24 & \\
\hline 28 & Odontoponera denticulata $\mathrm{F}$. smith & 163 & 157 & 68 \\
\hline 29 & Pachycondyla cf. astuta F. Smith & 1 & & 1 \\
\hline 30 & Pachycondyla cf. nakasujii Yashiro et al & 6 & 1 & \\
\hline 31 & Pachycondyla nigrita (Mayr) & & & 1 \\
\hline 32 & Pachycondyla rufipes (Jerdon) & 9 & 58 & 1 \\
\hline \multirow[t]{2}{*}{33} & Pachycondyla sp1 of LD & 1 & 3 & \\
\hline & Subfamily Pseudomyrmecinae & & & \\
\hline 34 & Tetraponera attenuata (F. Smith) & & 19 & \\
\hline \multirow[t]{2}{*}{35} & Tetraponerasp5 of LD & & 2 & \\
\hline & Total & 613 & 1408 & 379 \\
\hline
\end{tabular}

Note: LD is abbreviation of collection of Nguyen Dac Dai and Nguyen Thi Phurong Lien.

Note: $(\boldsymbol{I})=$ secondary forest, $(\boldsymbol{I I})=$ acacia plantation, $(\boldsymbol{I I I})=$ mixed forests on limestone

Dominant species is the species which have more than 100 individuals in the habitat. Their list is shown in Table 2. There are three dominant species in the habitat (I), Pheidole noda, Odontomachus cf. monticola, and Odontoponera denticulate; four dominant species in the habitat (II), Odontoponera denticulata, Carebara diversa, Technomyrmex brunneus and Anoplolepis gracilipes; and only one dominant species in the habitat (III), Anoplolepis gracilipes. The reasons may be due to bioecological traits of the most abundant species as well as stochastic impacts.
The more dominant species, the fewer amounts of resources goes to concomitant species, therefore, the lower value in community species richness. The part of community resources used by the dominant species may be not a special case but can be a reflection of general pattern of resources distribution among species under specific environmental conditions. Correspondingly, in communities with higher dominance species, there might be more "strict" distribution of resources among concomitant species, which, in turn, might influence community species richness.

\section{Table 2. Dominant species in three habitats in Phu Luong, Thai Nguyen}

\begin{tabular}{|c|c|c|c|c|}
\hline \multirow[b]{2}{*}{ No } & \multirow{2}{*}{ Species name } & \multicolumn{3}{|c|}{ Number of individuals in each habitat } \\
\hline & & (I) & (II) & (III) \\
\hline 1 & Anoplolepis gracilipes (F. Smith) & - & 111 & 122 \\
\hline 2 & Carebara diversa (Jerdon) & - & 561 & - \\
\hline 3 & Pheidole noda Smith & 113 & - & - \\
\hline 4 & Odontomachus cf. monticola Emery & 160 & - & - \\
\hline 5 & Odontoponera denticulata $\mathrm{F}$. smith & 163 & 157 & - \\
\hline 6 & Technomyrmex brunneus Forel & - & 244 & - \\
\hline & Total & 436 & 1073 & 122 \\
\hline & D $(\%)$ & 71.1 & 76.2 & 32.2 \\
\hline
\end{tabular}

Note: $(I)=$ secondary forest, $(I I)=$ acacia plantation, $(I I I)=$ mixed forests on limestone 
The Shannon-Wiener's species diversity index (H') (Table 3 ) indicated that in the year round, diversity was the highest in the habitat (II), followed by the habitat (I) and lowest in the habitat (III). Moreover, the highest value of the Evenness index (J') of ants was in the habitat (III), followed closely by the habitat (I), and lowest in the habitat (II). This indicates that a relatively equal abundance of species was present in the three habitats.

Table 3. Shannon-Wiener's species diversity index (H') and Evenness index ( $J$ ') of ant in each habitat in Phu Luong, Thai Nguyen

\begin{tabular}{lccc}
\multicolumn{1}{c}{ Habitats } & Number species & Number specimen & J' \\
\hline Natural evergreen raining forest (I) & 22 & 613 & 0.64 \\
Acacia plantation (II) & 28 & 1408 & 0.62 \\
Mixed forests on limestone (III) & 13 & 379 & 0.71
\end{tabular}

Figure 1 showed that the similarity, using Bray-Curtis similarity coefficient $(\mathrm{S})$ to determine the similarity in community composition, was highest between the mixed forests on limestone and the acacia plantation (35\%), and then between the natural evergreen raining forest and the other two habitats, acacia plantation and mixed forests on limestone $(32 \%)$, indicating that both ant species diversity and community composition were varied in these three sites which may relate to their different habitats.

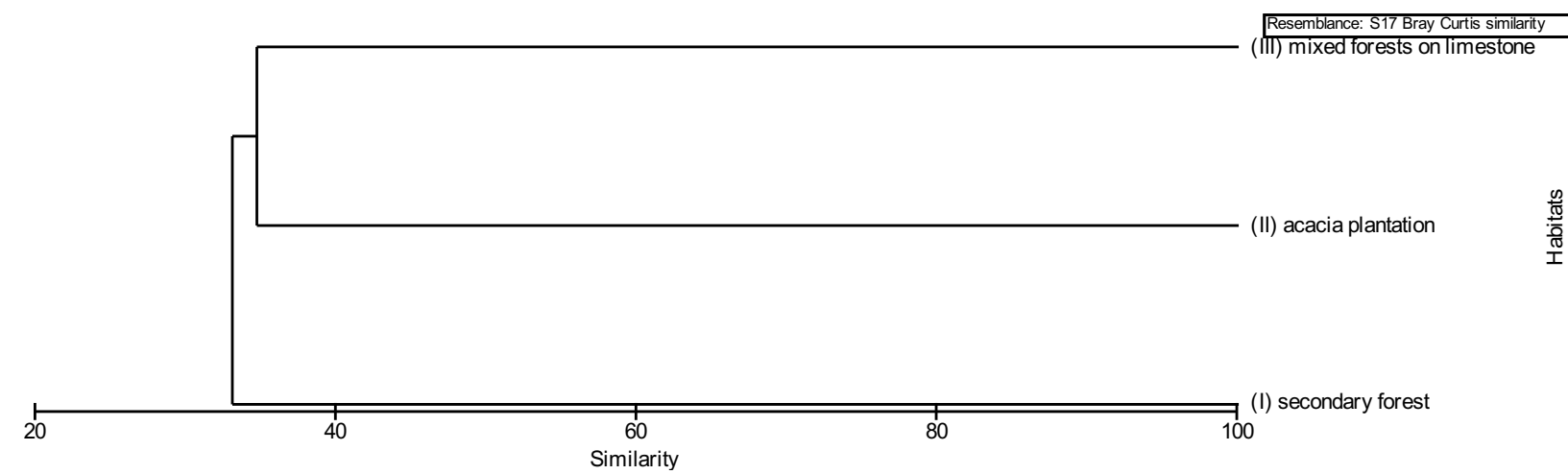

Figure 1. The Bray-Curtis similarity coefficient of ants from three habitats in Phu Luong, Thai Nguyen

\section{Conclusion}

The difference in habitats may reflect the different of species composition. Some species were found in all three habitats, while other species were more specialized being found only in a specific habitat. Each habitat has different number of dominant species. In this study, there are six dominant species recorded, in which three dominant species were found in the habitat (I), four dominant species were found in the habitat (II), and only one dominant species found in the habitat (III). The Shannon-Wiener's species diversity index (H') was the highest in the habitat (II) and lowest in the habitat (III). Therefore, species diversities in the habitats are different: habitat (II) has the highest number of species, followed by the habitat (I), and the lowest number of species is in the habitat (III). The species similarity coefficients $(\mathrm{S})$ of ants in each habitat are relatively low. The reason may be the difference vegetation and condition in each habitat. In addition, this is only a comparative assessment of diversity and abundance of research subjects.

\section{Acknowledgements}

We thank Dr. S. Yamane and Dr. K. Eguchi for their help in identifying ant specimens. This research was supported by Vietnam Academy of Science and Technology under grant number VAST04.08/15-16.

\section{References}

[1] Adis, J. and Latif, M. 1996. Amazonian arthropod respond to El Nino. Biotropica, 28, 403-408.

[2] Anderson, A.N. 1990. The use of ant communities to evaluate change in Australian terrestrial ecosystems: A review and recipe. Proceedings of Ecological Society Australia, 16, 347-257.

[3] Beattie, A. J., and L. Hughes. 2002. Ant-plant interactions. In Herrera and Pellmyr 2002, 35 - 211. Maryati, M. 1996. A review of research on ants in Malaysia. In: Biodiversity and the Dynamics of Ecosystems. I.M. Turner, C.H. Diong, S.S.L. Lim and P.K.L. Ng, (eds.). Diversitas in the Western Pacific and Asia series 1, 373-383.

[4] Bolton, B. 1994. Identification guide to the ant genera of the world, Harvard University Press, Cambridge, USA, 222.

[5] Clarke, KR, Gorley, RN, 2006. PRIMER v6: User Manual/Tutorial. PRIMER-E, Plymouth, 192pp.

[6] Eguchi K., Bui T.V. and Yamane S., 2011. Generic Synopsis of the Formicidae of Vietnam (Insecta: Hymenoptera), Part I - Myrmicinae and Pseudomyrmecinae. Zootaxa 2878: 1-61.

[7] Eguchi K., Bui T.V. and Yamane S., 2014. Generic Synopsis of the Formicidae of Vietnam (Insecta: Hymenoptera), Part II-Cerapachyinae, Aenictinae, Dorylinae, Leptanillinae, Amblyoponinae, Ponerinae, 
Ectatomminae and Proceratiinae. Zootaxa 3860: 001 046.

[8] Khoo, K.C. and Chung, G.F. 1989. Use of black cocoa ant to control mirid damage in cocoa. The Planter, Kuala Lumpur, 65, 370-383.

[9] Kritsaneepaiboon, S. and Saiboon, S. 2000. Ant species (Hymenoptera:Formicidae) in longkong (Meliaceae: Aglaia dookkoo Griff.) plantation. Songklanakarin Journal of Science and Technology, 22(3), 393-396.

[10] Nguyen Thi Thu Cuc, 2005. Research on citrus weaver ant Oecophylla smaragdina (Hym.: Formicidae) and benefits of its use on citrus in the Mekong
Delta of Vietnam. Proceedings of the $5^{\text {th }}$ Vietnam national conference on Entomology. Hanoi 2005: 606611. (in Vietnamese)

[11] Nguyen Dac Dai, Nguyen Thi Phuong Lien, 2015. A survey of ants (Hymenoptera: formicidae) in Phu Luong, Thai Nguyen province. Proceedings of the 6th national scientific conference on Ecology and Biological Resources. Hanoi 2015: 510-513.

[12] Pearson, L.D. and Derr, A.J. 1986. Seasonal patterns of lowland forest floor abundance in southern Peru. Biotropica, 18, 244-256. 